\title{
Media's Role in Televised Media Coverage and Its Influence on Terrorist Attacks in Nairobi County, Kenya
}

\author{
K. Nyakomitah,, P. Mwaeke, and L. Mareri
}

\section{ABSTRACT}

With the turn of the century, Kenya's capital, Nairobi, has had its share of terrorist activity. Due to their nature, global media houses have centred on these occurrences as they have formed the focal point during their immediacy. This has led to the rise of media; in all its variety, as a reliable ate truthful source of information: on the other hand, terrorists have used the media as a veritable and strong propaganda tool. This is in line with the main aim and intent of terrorism; the spread of fear and it also feeds to the belief by various terrorist groups that media is one of their biggest investments. This study sought to examine media's role in televised media coverage and it's influence on terrorist attacks in Nairobi County, Kenya. The sample size for the study was derived from 110 officers from the AntiTerror Police Unit, a section of the Directorate if Criminal Investigations and informants numbering to 14 from television editors, freelance reporters, and across civil society. The data was collected through questionnaires and interview guides for the officers from ATPU and respondents from the media and civil society respectively. It was further analysed using SPSS and presented through the use of frequency distribution tables and bar graphs; other modes include inferential statistics of linear regression and Chi square. The study revealed that there was a significant effect on the security situation in Nairobi due to televised media coverage of terrorist attacks. The study revealed a significant relationship between media coverage of terrorist incidents and increased insecurity in Nairobi. $(\chi 2=9.499 \mathrm{a}, \mathrm{p}=0.023)$. The recommendations include the development of proportionality in the reporting on terrorist attacks. This is because an overemphasis on terrorist threats has an inadvertent advancement of terrorism and terrorist activities. There is therefore a need for care by journalists lest they be used as vehicles of propaganda by terrorists. This is due to the power that is inherent in misinformation in denying the general public independent reporting and the resultant understanding that comes with it. It is recommended that there be a limit as to the amount and type of information released to the media and eventually to the public in the event of a terrorist attack; this helps in averting the spread of terrorist propaganda and the misinformation of the public.

Keywords: Hard News, Media, News Story, Terrorism

\section{INTRODUCTION}

It is inarguable that media plays a central place in the politics of nations and the world at large. Since the time print and broadcast media came into being, they have been used both for good and bad ends. The capacity of media as a galvanizing and informative tool has coexisted with its capacity to be misused as a means to spread and entrench negative propaganda. For example, the swift and wide-reaching capacity of radio was successfully used by the Nazi propaganda team to spread its vile doctrine (Abadie, 2006), by the Interahamwe militia in Rwanda in the build-up and during the country's genocide in 1994 (YanagizawaDrott, 2014; Levy, 2016), and also during the Balkan Wars in the 1990's; specifically in Croatia (Doward, 2015). Despite time and space being dedicated to the above use of media in propaganda, it can be said that not much literature and research has been devoted to the link between terrorism and media coverage. This is however does not demote that there lacks allusion to such dynamism (e.g., see Rather, 2012; Doward, 2015, Levy, 2016; Rudoy, 2016).

As has been seen above, the media wields a strong and central influence in the news content that will be disseminated to the populace: this in turn influences belief patterns and can be used to set and deliver certain nationalistic and global agenda. 
In line with this paper's theme, there has been an exponential increase in the number of serious terrorist attacks around the world from the turn of the century. Few scholars (Walsh, 2010; Rudoy, 2016) attribute this to increased media coverage of terrorist activities. In many countries including Kenya, this has brought about increased and profound war costs on loss of human lives and serious devastating effects to economic growth that include negative consequences on foreign trade, (including) stock prices, and tourism in addition to other hidden costs of psychological fear and terror among individuals (Weimann, 2004).

According to recent researchers Mueller\& Stewart, 2014 the ensuing Global War on Terror has placed on states mammoth costs that has translated to increased productivity loss among many societies of the world. For example, according to GTL (1998) report, the war on terror was said to have a cumulative cost of US\$3.3 or US\$3.7 trillion. These mammoth costs of this crime have compelled researchers to dig into the underpinnings and rigor of the causes and consequences or effects of terrorist incidents. Weimann (2004) argues that traditionally terrorism has been used as a means of passing a message: for example, fronting some religious agenda as was done by the Al Qaeda and Taliban or expressing desire for political realignment as was the case of the Kurds in fighting for an independent state. Despite the fact that opinion is still divided as to the existence of any contributory effect between media and terrorism, it is inarguable that one of the strategies known to be used by terrorists to catch public attention is by use of the media.

According to Campos and Gassebner (2013), public attention is a veritable need for the continuance and survival of any terrorist activity; the media plays a central and integral role in the provision of almost unquestionable platform in the promotion of the terrorist group's agenda. This provides a huge capacity that needs to be exploited in the dissemination of news across the world; whether this news is devastating in its nature is of little consequence (Frey \& Luechinger, 2003). In addition, Krueger and Male (2003), describe terrorism as "usually intended to influence an audience and emphasize the intention of terrorists to cause fear and terror among a target audience rather than the harm caused to the immediate victims." Frey and Luechinger (2003), posited that the seeking of publicity by terrorists is aimed at ensuring that their cause receives maximum attention. Michael Jeter, conducted research based on reporting on the New York Times on more than 60,000 terrorist attacks between 1970 and 2012. He noted that "during recent years, the world has witnessed terrifying formidable increase in the number of terrorist attacks". In 1998 alone, The Global Terrorism Database listed 1,395 attacks; this figure has clearly risen in the recent past to reach an all-time high of 8,441 in 2012. Blondheim and Liebes (2018), however aver that nature and type of terrorist attacks may elicit different responses in terms of media coverage.

Despite the importance of catching the public eye in order to address a terrorist organization's goals, media around the world have reacted differently to each terrorist episode (Blondheim \& Liebes, 2018). This is despite the innate need for terrorist organisations to not only control the story, how it comes out and most importantly, when it gets out. Some of the most effective uses of (international) media in spreading terrorist propaganda include: the 1979 siege of the American Embassy in Tehran by Islamic fundamentalists. The world was for 444 days daily informed of the new power in Islamic fundamentalism (Sick, 1985). A few years before in 1972, members of Black September received front row attention when they not only stormed the Munich Olympics but also did so with the assurance that all of the world's major media houses would be present and more often than not, beaming the games and all its happenings live. The third example was the 9/11 terrorist attack on New York. That it was on a morning (in New York) and the world's premier news would inevitably be focused there for updates on the political and commercial developments, AL Qaeda was able to bring terror to literally, living rooms across the globe. The live beaming of the second plane ramming into the second tower of the WTC remains a vivid and unchanging memory on anyone who witnessed it regardless of the geographical location.

In order to realise the need to have a veritable and ready means of reaching the world, some terrorist groups have taken over broadcast outlets. in the aftermath of $9 / 11$, there was need by media executives to ensure that the commandeering of television or radio stations was prevented. This led to various terrorist groups forming their own broadcast establishments where there was availability of resources and that the security of these institutions was guaranteed (Weinberg \& Davis, 1989). The other concern has been the seemingly sympathetic overtures by established media houses to terrorist entities and their activities. A good example would be Al Jazeera after 9/11: it used to broadcast videotapes of warnings of impending terrorist attacks by Osama bin Laden to the West. The rapid development of the internet has introduced a new frontier in broadcast capacity as many terrorist groups have their own websites where their propaganda is easily disseminated (Weimann, 2004).

Apparently as has been stated elsewhere, most previous studies have tried to establish the correlation between (mass) media and terrorism. However, the nature of the relationship still exists in the grey areas. This study will therefore seek to examine the security effects of media coverage on terror attacks in Nairobi County, Kenya.

Due to its sensitive nature, speculation is rife that the amount of media coverage that terrorist activities receive, which inevitably result in attention to the terrorist groups and individuals, is serving as encouragement for future attacks. This can be discounted by understanding that while horrific incidents can 
be instigated with a nefarious end in mind, the media views these incidents as news scoops; items which are not only newsworthy but which bring the limelight to the specific news corporation. The nature of the media as a reliable source of information, the kind to be sought when marketing and publicity are desired, coincides with the nature of terrorism; inadvertently, this plays a key role in highlighting the terrorists' heinous attacks. Besides, this relationship has never been adequately investigated, analysed, or documented, especially in Kenya. This study, therefore, examined the security implications of televised terror attacks in Nairobi County, Kenya.

\section{Methodology}

\section{A. Research Design}

This study used descriptive survey design which is appropriate when the subjects have responded to a series of questions or statements in the form of a questionnaire of interview (Jackson, 2003). According to Perl (1997), descriptive survey is optimal when the researcher is seeking information about the opinions, perceptions and attitude and a whole range of social issues. It is mainly concerned with finding out the What, the Where, the How and the Who of a phenomenon in a study.

Based on the sensitivity of the subject matter, the descriptive survey design offered an atmosphere where the sharing of views, suggestions and experiences on the televising of terror attacks in Nairobi could be done in a relatively anonymous and hence safe environment.

\section{B. Location of Study}

The area of the research was in Nairobi County as shown in Figure 3.1. Founded in 1899 as a trading post, Nairobi began and still remains the capital of the country; and later on as both as the administrative and commercial capital and principal county in the devolved system under the 2010 constitution.

\section{RESUltS AND DisCUSSION}

The study sought to ascertain the extent to which people feel about Nature of Televised Media Coverage of Terrorist Attacks. The results were presented under the following sub-themes.

\section{A. Extent of Media's Role and Nature of Televised Terror Attacks}

The study sought to investigate the role of media in covering terror attacks and the nature of terror attacks that are televised. The responses were analysed, and the results were presented Table I.

TABLE I: OBJECTIVITY OF MEDIA COVERAGE

\begin{tabular}{cccccc}
\multicolumn{2}{c}{ TABLE I: OBJECTIVITY OF MEDIA COVERAGE } \\
\hline \hline & Frequency & Percent & Valid Percent & $\begin{array}{c}\text { Cumulative } \\
\text { Percent }\end{array}$ \\
\hline \multirow{3}{*}{ Valid } & Disagree & 9 & 7.9 & 8.2 & 8.2 \\
& Agree & 45 & 39.5 & 40.9 & 49.1 \\
& Strongly Agree & 56 & 49.1 & 50.9 & 100.0 \\
\hline \hline
\end{tabular}

The results in Table I above show that slightly more than half (50.9\%) of the respondents strongly agreed that the media in Kenya is very objective in covering terror; only nine respondents representing $8.2 \%$ of the sample population had a contrary opinion. These findings are in line with Picard (1993) who argues that while media coverage is not essential to terrorist objectives, it is nonetheless important, as it helps define the social meaning of terrorist acts and frequently "confers status" upon terrorists and their causes.

\section{B. Uniformity of Reporting Terrorist Attacks}

The study sought to determine the Uniformity of Media houses in reporting terror incidents. The results are presented in Table II.

TABLE II: UNIFORMITY OF REPORTING TERRORIST ATTACKS

\begin{tabular}{ccccc}
\hline \hline & & Prequency & Percent & Valid Percent \\
\hline \multirow{4}{*}{ Valid } & Strongly Disagree & 9 & 7.9 & 8.2 \\
& Disagree & 42 & 36.8 & 38.2 \\
& Agree & 40 & 35.1 & 36.4 \\
& Strongly Agree & 19 & 16.7 & 17.3 \\
\hline \hline
\end{tabular}

As shown in Table II above, the results indicates that only $8.2 \%$ of the respondents strongly disagreed that all terrorist incidents and attacks are uniformly covered by the media. 
European Journal of Humanities and Social Sciences www.ej-social.org

\section{Influence of Media Compromising in Advancing Terrorist Agenda}

The study sought to establish the influence of Media Compromise in advancing terrorist activities. Koehler (2016) states that journalists need to be aware that, as soon as they step into the process of reporting on terrorism, they are no longer neutral. To maintain as much objectivity as possible, Eid (2014) argues that the media needs to avoid being manipulated by either terrorist or government propaganda.

\section{Relationship between Televised Media Coverage of Terror Attacks and Security Implication in Nairobi County}

To further understand the implication that excessive media coverage can result to security in the Nairobi county, the following hypothesis was tested to establish existence of any relationship

$\mathbf{H}_{01}$ : There is no statistically significant relationship between media coverage of terror attacks and security implication in Nairobi County, Kenya

As shown in Table III, the result was significant: $\chi^{2}(1, \mathrm{~N}=110)=9.499 \mathrm{a}, \mathrm{p}=0.023$.

The calculated Chi-square was computed and then compared with the critical points of the theoretical Chi-square distribution to produce an estimate of how likely or unlikely this calculated value was if the two variables were in fact independent.

TABLE III: RELATIONSHIP BETWEEN EXCESSIVE MEDIA COVERAGE OF TERROR INCIDENTS AND INSECURITY

\begin{tabular}{cccc}
\hline & Value & df & Asymp. Sig. (2-side) \\
\hline Person Chi-Square & $9.499^{\mathrm{a}}$ & 3 & 0.023 \\
Likelihood Radio & 10.987 & 3 & 0.012 \\
Linear-by-Linear Association & 0.120 & 1 & 0.729 \\
\hline N of Valid Cases & 110 & & \\
\hline \hline
\end{tabular}

The chi-square test was used to determine whether there is a significant difference between the expected frequencies and the observed frequencies in one or more categories. According to the chi-square tests, the chi -square analysis showed a value of 9.499 at 3 degrees of freedom. This value was more than $P$ value of 0.023 . Since the p-value $0.023<0.05$ at $5 \%$ level of significance, the null hypothesis was rejected. Thus, there exist a statistically significant relationship between televised media coverage of terror attacks and security situation in Nairobi County, Kenya.

To further test for the hypothesis, OLS linear regression was carried out as shown below.

\begin{tabular}{cccccc}
\multicolumn{4}{c}{ TABLE IV: MODEL SUMMARY OF LINEAR REGRESSION } \\
\hline \hline Model & $\mathrm{R}$ & $\mathrm{R}$ Square & Adjusted R Square & $\begin{array}{c}\text { Std. Error of the } \\
\text { Estimate }\end{array}$ & Durbin-Wats \\
\hline 1 & $0.033^{\mathrm{a}}$ & 0.76 & 0.84 & 0.499 & 0.486 \\
\hline \hline
\end{tabular}

a. Predictors: (Constant), Televise media coverage of terror attacks

b. Dependent Variable: security implication

From the OLS regression results, the explanatory power of the model that shows how well televised media coverage of terror attacks influences security situation in Nairobi County, Kenya was given by Adjusted R-square 0.084 implying that excessive reporting of media coverage of terror attacks influenced security situation negatively by only $8.4 \%$. The remaining $91.6 \%$ indicates that excessive media coverage of terror attacks led to heightened security in Nairobi County rather than more attacks and increasing terrorist impetus more attacks. Mass media can play a contributory role in amplifying negative impact of terrorism.

From the table above, the results indicate that the OLS model had a constant value of 1.318 while coefficient of televised media coverage of terror attacks was 0.033 which is statistically significant since pvalue $0.000<0.05$ at $5 \%$ level of significance. This implied that, holding other factors constant, a unit change in excessive media coverage of terror attacks resulted to 3.3-unit increase in security implication in Nairobi County, Kenya.

\section{SUMMARY, CONCLUSIONS, AND RECOMMENDATIONS}

\section{A. Summary}

Based on the objective of the study which was to determine the nature of televised media coverage of terror attacks in Nairobi County, Kenya, slightly more than half (50.9\%) of the respondents strongly agreed that the media in Kenya is very objective in covering terror attacks.

Equally, $50.9 \%$ of the respondends agreed that media coverage of terror incidents gives terrorist a leverage to their heinous activities. Only $8.2 \%$ of the respondends strongly disagreed that all terrorist incidents and attacks are uniformly covered by the media while forty-two respondents representing $38.2 \%$ of the sample population agreed with the statement that sometimes that terror incidents are not uniformly 
covered by media houses.

Fifty respondents representing $45.5 \%$ of the study population strongly agreed that media reporting/ coverage of terrorist attacks and incidents is mainly driven by commercial motive by the respective media houses.

\section{B. Conclusions}

The study concluded that media covering of terror attacks might offer leverage to terrorist to pursue their heinous attacks. Terrorist attacks with more deaths, fatalities and injuries are given much media coverage than mere explosions with less causalities. Also, excessive media coverage of terror attacks increases terrorist impetus for more attacks.

Analysis also indicates that inadvertent advancement does occur; mainly due to the communication of terrorism through reporting. In this context, this paper proposes that different elements of inadvertent advancement can be mitigated by responsible and ethical reporting practices.

\section{Recommedations}

Drawing from the research findings and conclusions discussed herein, the study makes the following recommendations:

i. That inaccurate information, which spreads disproportionate fear, does not get reproduced, and that the media's framing of terrorism incidents does not encourage the perpetuation of prejudices and stereotypes.

ii. Reporting on terrorism needs to be proportionate. Overemphasizing the threat of terrorism amplifies its negative impact and may inadvertently advance terrorist objectives.

iii. As a matter of policy, media coverage of terror incidents should be limited to information provided by incident commanders to help avert any forms of terrorist propaganda and misinformation.

The researcher suggests further research on the following areas:

i. To determine the effect of online media coverage of terror attacks on security management

ii. Challenges encountered by security apparatus in against fighting terrorism.

\section{CONFLICT OF INTEREST}

Authors declare that they do not have any conflict of interest.

\section{REFERENCES}

Abadie, A. (2006). Poverty, Political Freedom, and the Roots of Terrorism. American Economic Review, 96(2), 50-56.

Akhavan, M. R., \& Ramaprasad, J. (2018). Framing and ideology: A comparative analysis of U.S. and Chinese newspaper coverage of the Fourth United Nations Conference on Women and the NGO forum. Mass Communication \& Society, 1, 131152.

Archetti, C. (2014). Terrorism, Communication and the Media. In C. Kennedy Pipe, G. Cubb, \& S. Mabon (Eds), Terrorism and Political Violence. London: Sage.

Backholm, K., \& Bj“orkqvist, K. (2012). Journalists' emotional reactions after working with the Jokela school shooting incident. Media, War \& Conflict, 5, 175-190. Doi: 10:1177/17506 35212440914.

Blondheim, M., \& Liebes, T. (2018). From Disaster Marathon to Media Event: Live Television's Performance on September 11. In A.M. Noll (Ed.), Crisis Communications: Lessons (pp. 185-97).

Borger, J. (2016). French Media to Stop Publishing Photos and Names of Terrorists. The Guardian, https://www.theguardian.com/media/2016/jul/27/french-media-to-stop- publishing-photos-and-names-of-terrorists.

Campos, N. \& Gassebner, M (2013). International terrorism, domestic political instability, and the escalation. Economics \& Politics. $25(1), 27-47$.

Chatterji, S. (2011). Politicking with terrorism coverage. The Economic Times of India.

Chiang, C.F, \& Knight, B. (2011). Media bias and influence: Evidence from Newspaper endorsements. The Review of Economic Studies, 78(3), 795-820.

Chomsky, N. \&. Herman, S. (2010). Manufacturing consent: The political economy of the mass media. New York: Random House. Crenshaw, M. (1981). The Causes of Terrorism. Comparative Politics, 13(4), 379-399.

Connelly, L. M. (2014). Ethical considerations in research studies. MedSurg Nursing, 23(1). link.gale.com/apps/doc/A360608990/AONE?u=anon e90681a8\&sid=googleScholar\&xid=ae5ddbe8.

Debatin, B. (2016). Plane Wreck with Spectators: Terrorism and Media Attention. In B.S. Greenberg (Ed), Communication and Terrorism: Public and Media Responses to 9/11 (pp. 163-74). Cresskill, NJ: Hampton Press.

Della Vigna, S., Enikolopov, R., Mironova, V., Petrova, M., \& Zhuravskaya, E. (2014). Cross-Border Media and Nationalism: Evidence from Serbian Radio in Croatia. American Economic Journal: Applied Economics, 6(3), 103-132. http://www.jstor.org/stable/43189491

Doward, J. (2015). Media Coverage of Terrorism 'Leads to Further Violence'. The Guardian. https://www.theguardian.com/media/2015/aug/01/media- coverage-terrorism-further-violence.

Du, Y. R., \& Cheng, K. L. (2013). Framing the 2011 Egyptian revolution within ideological boundaries: One incident, three stories. International Communication Research Journal, 48(3-4), 27-51.

Eid, M. (Ed.). (2014). Exchanging Terrorism Oxygen for Media Airwaves: The Age of Terroredia. IGI Global.

Enders, W., \& Hoover, G. (2012). The Nonlinear Relationship between Terrorism and Poverty. The American Economic Review, $102(3), 267\{272$.

Enders, W., \& Sandler, T (2000). Is Transnational Terrorism Becoming More Threatening? A Time-series Investigation. Journal of Conflict Resolution, 44(3), 307- 332. 
European Journal of Humanities and Social Sciences www.ej-social.org

Frey, B. S. \& Luechinger, S. (2003). How to fight terrorism: Alternatives to Deterrence. Defence and Peace Economics, 14(4), 237249.

Frey, B. S., Luechinger, S., \& Stutzer, A. (2007). Calculating tragedy: Assessing the costs of terrorism. Journal of Economic Surveys, $21(1), 1-24$.

Gassebner, M. \&. Luechinger, S. (2011). Lock, Stock, and Barrel: A Comprehensive Assessment of the Determinants of Terror. Public Choice. 149 (3-4), 235-261.

Greenbaum R.T., Dugan L, La Free G. (2007). The Impact of Terrorism on Italian Employment and Business Activity. Urban Studies, 44(5-6), 1093-1108. doi:10.1080/00420980701255999.

Haravuori, H., Suomalainen, L., Berg, N., Kiviruusu, O., Marttunen, M. (2011). Effects of media exposure on adolescents traumatized in a school shooting. Journal of Traumatic Stress, 24, 70-77. doi:10.1002/ jts.20605.

Humud, C. E., Arieff, A., Blanchard, L. P., Blanchard, C. M., Sharp, J. M., Katzman, K. (2014). Al Qaeda-Affiliated Groups: Middle East and Africa. International Journal of Terrorism \& Political Hot Spots, 9(2-3), 65-116.

Koehler, D. (2016). Right-Wing Extremism and Terrorism in Europe: Current Developments and Issues for the Future. PRISM, 6(2), 84-105. http://www.jstor.org/stable/26470450.

Kothari, C. R. (2004). Research Methodology: Methods and Techniques. New Age International.

Krueger, A. B. \& Male, J. C. (2003). Education, poverty and terrorism: Is there a causal connection? Journal of Economic Perspectives, 17(4), 119-144

Larcinese, V., Puglisi, R., \& Snyder, J. M. (2011). Partisan bias in economic news: Evidence on the agenda-setting behaviour of US newspapers. Journal of Public Economics, 95(9), 1178- 1189.

Lee, J., \& Craig, R. (2012). News as an ideological framework: Comparing US newspapers' coverage of labour strikes in South Korea and Poland. Discourse \& Society, 3, 341-363.

Levy, B.H. (2016). We Should Relegate Terrorists To The Obscurity Of Their Own Infamy. The Guardian, 13(5), 119-144.

Li, D. (2004). Echoes of Violence: Considerations on Radio and Genocide in Rwanda. Journal of Genocide Research, 6(1), 9-27.

Mahmoud, E. (2013) The New Era of Media and Terrorism. Studies in Conflict \& Terrorism, 36(7), 609-615.

McKenzie, S. (2016). French media stop publishing terrorist images: The argument for and against Terrorism. CNN. http://edition.cnn.com/2016/07/28/europe/ French-media-terrorist-photographs/.

Mindframe, L. (2014). Reporting Suicide and Mental Illness: A Mind Frame Resource for Media Professionals. www.mindframemedia.info/.

Mueller, J., \& Mark, G. S. (2014). Evaluating Counterterrorism Spending. Journal of Economic Perspectives, 28(3), 237-48.

Mugenda, M. O., \& Mugenda G. A. (2003). Research Methods: Qualitative and Quantitative Approache. Nairobi: Africa Centre for Technology Studies.

Nassiuma, D. K., \& Mwangi, J. (2004). Statistical Methods for Information Analysis: An Introduction. Egerton University Press.

Orodho, A. J. \& Kombo, D. K. (2002). Research Methods. Nairobi: Kenyatta University.

Papacharissi, Z., \& de Fatima Oliveira, M. (2018). News frames terrorism: A comparative analysis of frames employed in terrorism coverage in U.S. and U.K. newspapers. The International Journal of Press/ Politics, 13, $52-74$.

Perl, R. (1997). Terrorism, the media, and the government: perspectives, trends, and options for policymakers. CRS Issue Brief. 95112.

Picard, R.G. (1993). Media Portrayals of Terrorism: Functions and Meaning of News Coverage. Ames: Iowa State University Press.

Pries-Shimsh, Y. (2005). Creating a citizenry prepared for terrorism: Education, media, and public awareness. International Institute for Counter-Terrorism.

Rather, D. (2012). Media's balancing act with Terrorism. CNN. underhttp://edition.cnn.com/2012/09/11/opinion/rather-media-andterrorism/.

Rohner, D., \& Frey, B. S. (2007). Blood and ink! The common-interest-game between terrorists and the media. Public Choice, 133(12), 129-145.

Rudoy, M. (2016). The media must stop encouraging terrorists. The Huffington Post, availableunderhttp://www.huffingtonpost.com/marty-rudoy/the-media-must-stop- encou_b_11043326.html.

Scheufele, D. A., \& Tewksbury, D. (2007). Framing, agenda setting, and priming: The evolution of three media effects models. Journal of Communication, 57(1), 9-20.

Semetko, H. A., \& Valkenburg, P. M. (2010). Framing European politics: A content analysis of press and television news. Journal of Communication, 50(2), 93-109.

Severin, W. J., \& Tankard, J. W. (2011). Communication theories: Origin, methods, and uses in the mass media (5th ed.). New York, NY: Longman.

Shaw, D., McCombs, M. (1972). The Agenda-setting unction of the Mass Media. Public Opinion Quarterly, 36, 176-87.

Shoemaker, P. J., \& Reese, S. D. (2016). International terrorism and news coverage: A comparative study between the U.S. and China. Paper presented at International \& Development Communication Division, the 57th Annual Conference of ICA, San Francisco, CA.

Sick, G. (1985). All Fall Down: America's Tragic Encounter with Iran. London: I.B. Tauris.

Van Dijk, T. (2018). Ideology. London, England: SAGE.

Walsh, J.I. (2010). Media attention to terrorist attacks: Causes and consequences. Institute for Homeland Security Solutions, Research Brief.

Weimann, G., \& C. Winn (1994). The Theater of Terror. New York: Longman.

Wilkinson, P. (1997). The Media and Terrorism: A Reassessment. Terrorism and Political Violence, 9(2), 51-64.

Weimann, G. (2004). Cyberterrorism: How Real is the Threat? United States Institute of Peace.

Weinberg, L., \& Davis, P.B. (1989). Introduction to Political Terrorism. New York: McGraw- Hill.

Yanagizawa-Drott, D. (2014). Propaganda and conflict: Evidence from the Rwandan Genocide. The Quarterly Journal of Economics, 129(4), 1947-1994. 